\title{
"Contigo aprendí..." Notas para una agenda de investigación sobre izquierdas y feminismos en el pasado reciente
}

Resulta imposible comenzar a presentar este dossier sin hacer referencia al contexto de producción en el cual se enmarca y sus efectos sobre las relaciones de género. A escala mundial y como nunca antes en la historia del capitalismo, la pandemia de covid-19 ha puesto de relieve el rol sistémico del trabajo de cuidado sostenido mayoritariamente por mujeres. Y no nos referimos solamente al intensificado trabajo dentro de las casas y el agotamiento que conlleva la feroz reconversión productiva al teletrabajo, presentado en forma edulcorada como "trabajo en pantuflas", sino también al trabajo en los comedores sociales y en los barrios donde el hambre y la desocupación golpea con fuerza y donde son las mujeres las que continúan poniendo el cuerpo (redobladamente), como las cientos de Ramonas Medina. ${ }^{1}$ Justamente cuando la marea verde parece extenderse por América Latina, cuando el feminismo se ha transformado en un movimiento social de masas internacional, el tándem capitalismo/pandemia configura el escenario para un nuevo agigantamiento de las brechas de género y las desigualdades de clase históricamente constituidas.

1. Ramona Medina era militante de la organización La Garganta Poderosa en la Villa 31 de Retiro. Murió de covid-19 en mayo de 2020 luego de haber denunciado durante semanas la falta de agua en la villa, una condición esencial para el cuidado durante la pandemia.

DOI: https://doi.org/10.46688/ahmoi.n19.321

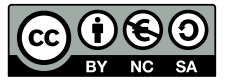

Obra bajo licencia Creative Commons 4.0 International (Atribución - NoComercial - Compartirlgual) 
Interpeladas y a la vez atravesadas por el contexto de características distópicas y la incertidumbre por el futuro, buscamos recuperar en la historia del pasado reciente conosureño experiencias que contribuyan a pensar el presente. Este dossier, entonces, es resultado de la convicción de que el encuentro entre marxismo y feminismo constituye un marco inescindible para la transformación social en clave emancipatoria.

En nuestra región, aún con distintos ritmos e intensidades, la historiografia con enfoque de género ha crecido notablemente en los últimos años proponiendo, no sin dificultades, un proceso de revisión y reescritura de carácter global. Esta historiografía se interesó en reponer a las mujeres en la Historia y la Historia a las mujeres, en comprender el significado de los sexos y los géneros y las razones de las desigualdades establecidas entre ambos.

Dentro de esta trama, destacamos los avances en el campo de estudios de las izquierdas en los años 70 y el lugar de las militancias femeninas en ellas; y también la aparición más reciente de trabajos preocupados por recuperar las huellas del feminismo, de su larga y discontinua historia y de las genealogias que lo surcan y que contribuyen, sin dudas, a comprender que su potencia, extensión y transversalidad actual es tributaria de las experiencias pioneras. Que dialoga con ellas, que aprende de ellas y, más aún, que no podría explicarse sin adentrarse en esa historia. Sin embargo, especialmente en la historiografia argentina, poco se ha dicho sobre los enlaces entre los feminismos y las izquierdas desde el período que se abre con la transición a la democracia hasta el presente, a pesar de que los vínculos tanto teóricos como en el plano de las luchas concretas han sido constantes. Nuestra propuesta apunta a colocar los primeros mojones para intervenir en esa vacancia. El objetivo es colaborar en la reconstrucción de esas ricas trayectorias, que hablan de tensiones, sin dudas, pero también de encuentros y experiencias comunes que muchas veces fueron interpretados injusta y simplificadamente como un "matrimonio infeliz".

¿Cuánto el feminismo impactó en las izquierdas partidarias y autonomistas en los países de nuestra región? ¿En qué medida las izquierdas contribuyeron con la circulación de las ideas feministas en los sectores populares? ¿Qué entendian las izquierdas por feminismo? ¿Qué dificultades del orden político, pero también cultural debieron sortear las mujeres marxistas para reivindicar la necesidad de pelear por sus derechos como mujeres, primero, y para abrir una agenda dentro de sus organizaciones, después? ¿Quiénes fueron esas militantes que abrieron camino? ¿Con qué lecturas, bagajes, argumentos? ¿Qué batallas públicas y privadas debieron librar para ganarse un lugar en igualdad con los compañeros de militancia? Estas son algunas de las preguntas que nos atravesaron (y acompañaron) para pensar el presente dossier. 
El conjunto de trabajos que podrán leer a continuación propone una línea de indagación centrada específicamente en la relación entre izquierdas, feminismos y movimiento de mujeres en los países del Cono Sur. La elección de Uruguay, Argentina y Chile resulta deliberada porque permite pensar los procesos tanto en sus aspectos comunes, por ejemplo el desembarco de las ideas feministas en las izquierdas promediando los años 80 , así como en sus especificidades. Por caso, la configuración del campo de las izquierdas en cada país ha sido diferente atendiendo a procesos de caracteristicas locales que impiden nombrarla en un sentido unívoco. El peso de las estructuras partidarias y de las distintas corrientes del marxismo; de la influencia social alcanzada; de su capacidad para conformar alianzas más o menos amplias, son datos que también fueron determinando el modo de ingreso, circulación e integración de las ideas feministas en cada país.

De este a oeste abrimos el dossier presentando el caso de Uruguay a cargo de Ana Laura de Giorgi que reconstruye de manera sugerente y panorámica las genealogias del feminismo de izquierda entre la década de 1980 y la actualidad. En su artículo, la autora demuestra que el feminismo uruguayo fue construido en gran medida por mujeres que provenían de la izquierda, que mantenian su preocupación por la desigualdad de clase, pero que también centraron energías para denunciar y revertir la desigualdad de género. Por un lado, la experiencia del Frente Amplio y de los partidos que lo componen se transforma en la referencia central para transitar un recorrido no exento de tensiones, desplantes e indiferencias. Por otro, la emergencia más reciente de un feminismo renovado, radical y autónomo que desafia la moderación de los espacios partidarios.

El artículo de Natalia Casola analiza las vinculaciones entre las izquierdas partidarias, el feminismo y el movimiento de mujeres en Argentina entre finales de la última dictadura militar y los años 90. En su artículo demuestra que, lejos de la simplificación que ubica a la izquierda como un todo en controversia con el feminismo, cada organización encontró una manera de sostener las luchas de las mujeres en concordancia con sus estrategias politicas en el orden general. Para esta reconstrucción toma los casos del Partido Comunista (PC), Partido Comunista Revolucionario (PCR), Movimiento al Socialismo (MAS) y Partido Obrero (PO).

Cristina Viano se preocupa por adentrarse en los procesos de construcción del feminismo popular en el espacio de la izquierda autonomista que emerge en el contexto de las luchas contra el neoliberalismo y la rebelión social del 2001 en Argentina. Su eje es la problematización de la experiencia del Espacio de Mujeres que nació en el 2003 en el seno del mundo piquetero y adquirió densidad y fortaleza en una organización 
multisectorial, el Frente Popular Darío Santillán, donde se conjugaron planteos y prácticas que apuntaron, no sin dificultades ni contradicciones, a un horizonte prefigurativamente feminista y antipatriarcal.

Pasando a Chile el trabajo de Javiera Recabarren Robles reconstruye la militancia de las mujeres comunistas durante la dictadura militar de Pinochet, poniendo énfasis en las luchas sostenidas durante la década de 1980. La autora presenta el repertorio amplio de modalidades que tuvo la militancia femenina en el marco del $\mathrm{PCCh}$, a pesar de que el partido no se reivindicaba feminista. Una de las principales originalidades del texto es la reconstrucción de la división y jerarquización sexual de la militancia en el marco del Frente Patriótico Manuel Rodríguez.

Por último queremos subrayar los nexos entre la producción académica y el activismo político y social que han constituido una marca de origen en el hacer de la historia del pasado reciente y determinan, al menos parcialmente, su propio sentido de existencia. Y que en esa dirección aspiramos a que nuestros estudios permanezcan estrechamente vinculados al movimiento amplio feminista y de izquierda, y no se pierdan en una academización sin vasos comunicantes con la experiencia viva.

\section{Natalia Casola y Cristina Viano}

Universidad de Buenos Aires - Universidad Nacional de Rosario 